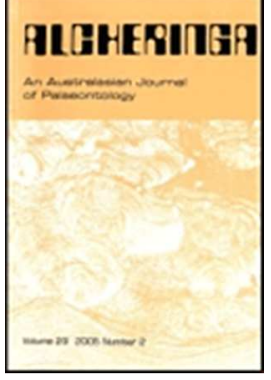

\title{
A new, extraordinary 'damselfly-like' Odonatoptera from the Pennsylvanian of the Avion locality in Pas-de-Calais, France (Insecta: 'Exopterygota')
}

\begin{tabular}{|r|l|}
\hline Journal: & Alcheringa \\
\hline Manuscript ID & Draft \\
\hline Manuscript Type: & Standard Research Article \\
\hline Complete List of Authors: & $\begin{array}{l}\text { Nel, Andre; Museum National d'Histoire Naturelle, entomologie; Museum } \\
\text { National d'Histoire Naturelle } \\
\text { Roques, Patrick; Muséum National d'Histoire Naturelle, entomologie } \\
\text { Prokop, Jakub; Univerzita Karlova v Praze Prirodovedecka Fakulta, } \\
\text { entomology; Univerzita Karlova v Praze Prirodovedecka Fakulta } \\
\text { Garrouste, Romain; Museum National d'Histoire Naturelle, Entomologie }\end{array}$ \\
\hline Keywords: & Odonatoptera, phylogeny, Moscovian, palaeoecology \\
\hline \multicolumn{2}{|c}{} \\
\hline
\end{tabular}


A new, extraordinary 'damselfly-like' Odonatoptera from the Pennsylvanian of the Avion locality in Pas-de-Calais, France (Insecta: 'Exopterygota')

ANDRE NEL, PATRICK ROQUES, JAKUB PROKOP and ROMAIN GARROUSTE

André Nel, Romain Garrouste [anel@mnhn.fr; garroust@mnhn.fr], Institut Systématique Evolution Biodiversité (ISYEB), Muséum national d'Histoire naturelle, CNRS, Sorbonne Université, EPHE, 57 rue Cuvier, CP 50, 75005 Paris, France.

Patrick Roques [patrick.roques93@wanadoo.fr] allée des Myosotis, Neuilly sur Marne, F93330, France.

Jakub Prokop [jprokop@natur.cuni.cz], Charles University, Faculty of Science, Department of Zoology, Viničná 7, CZ-128 44, Praha 2, Czech Republic.

Enigmaptera magnifica gen. nov, sp. nov., type genus and species of the new odonatopteran family Enigmapteridae, is described from the Moscovian of Avion (North of France). It is the sister group of the major clade Neodonatoptera, together in the new clade Paneodonatoptera. Its wing venation show important unique characters, never found in any other Odonatoptera. It is a further case of convergent wing petiolation in this superorder. Enigmaptera magnifica, like the protozygopteran Jacquesoudardia magnifica from the same outcrop, was probably living like the extant damselflies along the shores of lakes and rivers, hunting the small insects found in the same layers. These discoveries put a new light on the entomofaunistic diversity and complexity of the Late Carboniferous ecosystems.

Key words: Odonatoptera, fam., gen., sp. nov, phylogeny, Moscovian, palaeoecology. 
THE CARBONIFEROUS represents the first period of well-documented diversification of major lineages of winged insects in the fossil record (Engel et al. 2013). It is well-known for the numerous very large to 'giant' insects (the popular meganeurids or griffenflies). But small to very small insects were also flourishing during this period. The recently discovered outcrop at Avion in the department of Pas-de-Calais, is especially rich in small to very small wings mixed with thousands of plant fragments. It has led a very diverse entomofauna that comprises Palaeodictyoptera (including larvae), Archaeorthoptera, Caloneurodea, Paoliida, Dictyoptera, and the oldest representatives of the clades Acercaria and Holometabola (Nel et al. 2013, Prokop et al. 2013, 2014, Coty et al. 2014). It is dated to the Moscovian (Westphalian C/D or equivalent Bolsovian/Asturian). The fossil insects were found in 'Terril $\mathrm{N}$ 7', which contains rocks from the slag heap of coal mines 3 and 4 of Liévin, Bolsovian (Westphalian C, 308-311 Ma, 'faisceaux de Ernestine') /Asturian (Westphalian D, 306-308 Ma, ‘veines Arago, Dusouich, Marthe’; Bruno Vallois 2013 pers. comm.).

Here we describe a further very small wing that represents a new major clade of the superorder Odonatoptera. This wing is characterized by an extraordinary, unique pattern of wing venation. The Odonatoptera from Avion were already known by a Protozygoptera (Jacquesoudardia magnifica Prokop et al. 2014) and a Meganeuridae (Gallotupus ourdardi Nel et al. 2008).

\section{Materials and methods}

The material was collected by Patrick Roques. The fossil is provisionally stored in the collection of the Laboratory of Entomology in the Muséum National d'Histoire Naturelle, Paris (MNHN), France. The collection will ultimately be deposited in the Musée Géologique Pierre Vetter, Decazeville, France. The fossil was studied in a dry state using Olympus SZX-9 and Nikon SMZ 1500 stereomicroscopes. Line drawings of the venation pattern was drawn 
directly with the aid of a camera lucida. Photographs were taken using a Canon D550 digital camera with MP-E $65 \mathrm{~mm}$ and EF 50mm lenses. Original photographs were processed using the image-editing software Adobe Photoshop CS.

We mainly follow the wing venation nomenclature of Riek \& Kukalová-Peck (1984), Nel et al. (1993), and Jacquelin et al. (2017). The venational symbols used here are specified as follows: symbols in capitals denote the longitudinal veins (Arc: 'arculus', Ax0: basal primary antenodal crossvein, $\mathrm{ScA} / \mathrm{ScP}$ : subcostal anterior/posterior, RA/RP: radial anterior/posterior, IR: convex intercalary radial vein, MA/MP: medial anterior/posterior, $\mathrm{CuA} / \mathrm{CuP}$ : cubital anterior/posterior, AA: anterior anal vein).

\section{Systematic palaeontology}

Class INSECTA Linnaeus 1758

Infraclass PALAEOPTERA Martynov 1923

Superorder ODONATOPTERA Martynov 1932

Clade PANEODONATOPTERA taxon nov.

Included taxon. The new family Enigmapteridae, and the Neodonatoptera Bechly, 1996.

Etymology. Named in reference to the clade Eodonatoptera.

Autapomorphies. Wings slender and elongate; $\mathrm{MP}$ and $\mathrm{Cu}$ are at least shortly fused. The autapomorphies of the Neodonatoptera becoming: R and MA basally appressed together.

Family ENIGMAPTERIDAE fam. nov.

Type species. Enigmaptera magnifica gen. nov, sp. nov.

Diagnosis. Wing characters only: very narrow wing, basal part of MA closely parallel to R complete distal fusion of MP with R and MA, strongly convex MA re-emerging from $\mathrm{R}$ in 
arculus; very narrow anal area, $\mathrm{CuP}$ and $\mathrm{CuA}$ reduced to 'crossveins' between $\mathrm{MP}+\mathrm{Cu}$ and AA, RP1/2 very long.

Enigmaptera gen. nov.

Type species. Enigmaptera magnifica sp. nov.

Diagnosis. Very small wing, only $2.9 \mathrm{~mm}$ wide, and ca. $14 \mathrm{~mm}$ long.

Etymology. Named after the surprising and enigmatic wing venation of this taxon.

Enigmaptera magnifica sp. nov.

(Figs. 1-2)

Holotype. Specimen Avion 35 (counterimprint of basal half of a wing), collected by Patrick Roques; provisionally stored in the collection of the Entomological Laboratory, MNHN, Paris, France. The collection will be deposited in the Musée Géologique Pierre Vetter, Decazeville, France.

Locality and age. Moscovian (Westphalian C/D equivalent to Bolsovian/Asturian), 'Terril N 7', Avion, Pas-de-Calais, France.

Etymology. Named after the wonderful state of preservation of the preserved parts of this wing.

Diagnosis. As for the genus.

Description. Basal half of a wing, very well preserved, veins being with this normal convexity. Length of fragment $10.5 \mathrm{~mm}$, width of wing $2.9 \mathrm{~mm}$; C making a basal curve, no visible $\mathrm{ScA}$ nor $\mathrm{Ax}$; concave $\mathrm{ScP}$ straight, very long, progressively approximating $\mathrm{C}$ (width of area between $\mathrm{C}$ and $\mathrm{ScP}$ near wing base $0.45 \mathrm{~mm}$, at distal part of fragment $0.1 \mathrm{~mm}$ ), ScP ending on $\mathrm{C}$ at ca. $10.2 \mathrm{~mm}$ from wing base; six visible crossveins between $\mathrm{C}$ and $\mathrm{ScP}$; convex R (distally RA) parallel to $\mathrm{ScP}$, width of area between them $0.41 \mathrm{~mm}$, with seven 
preserved crossveins between them; convex RA and concave RP separating at $2.4 \mathrm{~mm}$ from wing base (arculus); RP separating into RP1/2 and RP3/4 just distally; base of convex secondary longitudinal vein IR2 just distal of point of separation of RP into RP1/2 and RP3/4; RP1/2, IR2, RP3/4 straight, with few crossveins between them defining long rectangular cells; fork of RP1/2, if present, in a very distal position, distal of apex of ScP; MA convex, but weaker and less convex than R, closely parallel to it, ending in $\mathrm{R} 2.3 \mathrm{~mm}$ from wing base, at the same point with MP; basal free part of concave MP oblique between base of MA and $\mathrm{Cu}$, $0.8 \mathrm{~mm}$ long, ending into $\mathrm{Cu}$; basal free part of $\mathrm{Cu} 0.7 \mathrm{~mm}$ long; concave $\mathrm{CuP}$ separating from $\mathrm{Cu} 0.2 \mathrm{~mm}$ basal of point of fusion between $\mathrm{MP}$ and $\mathrm{Cu}$, and ending into AA, a Z-like kink in $\mathrm{CuP}$ at point of fusion with $\mathrm{AA}$; $\mathrm{CuA}$ separating from $\mathrm{MP} 0.3 \mathrm{~mm}$ distal of point of fusion of $\mathrm{CuA}$ with $\mathrm{MP}$, a Z-like kink in $\mathrm{CuA}$ at point of fusion with AA; MP anteriorly curved and ending into $\mathrm{R}$ at the same point with MA; MA re-emerging from $\mathrm{R}$ at the same point with RP (arculus), very convex, $0.9 \mathrm{~mm}$ long before its fusion with $\mathrm{CuA}+\mathrm{CuP}+\mathrm{AA}$; then MA very straight; convex AA straight, progressively diverging from posterior wing margin and ending into MA; area between AA and posterior wing margin very narrow, 0.4 $\mathrm{mm}$ at its maximum width, $0.05 \mathrm{~mm}$ wide near wing base.

Discussion. This small wing is remarkable in the presence of a point of fusion of R, MA and MP $2.3 \mathrm{~mm}$ from wing base, with an arculus just distal to this point. Enigmaptera gen. nov. can be attributed to the Odonatoptera Martynov, 1932 because it has the following synapomorphies: wings with relatively undeveloped anal area; MP unbranched; anal brace with a Z-like kink in $\mathrm{CuP}$ and in $\mathrm{CuA}$ at their points of fusion with $\mathrm{AA}$; ScP fuses with the costal margin distinctly basal of wing apex (Bechly 1996). Enigmaptera shares with the Palaeodonatoptera Petrulevičius and Gutiérrez, 2016 the apomorphic fusion of MP with $\mathrm{Cu}$, while the Eugeroptera Petrulevičius \& Gutiérrez 2016 (only Eugeropteridae Riek 1983) have a vein $\mathrm{M}$ separated from $\mathrm{Cu}$ (at least in hind wing, probably in forewing too). Petrulevičius 
and Gutiérrez (2016) divided the clade Palaeodonatoptera into the Kukaloptera Petrulevičius \& Gutiérrez 2016 and Plesiodonatoptera Petrulevičius \& Gutiérrez 2016 [= (Argentinalidae Petrulevičius \& Gutiérrez 2016 (Geropteridae Petrulevičius \& Gutiérrez 2016 \& Neodonatoptera Bechly 1996))]. Enigmaptera shares with the Neodonatoptera the synapomorphy 'MP fused with $\mathrm{Cu}$ for a long distance', while in the Kukaloptera, Argentinalidae, and Geropteridae, MP is only fused for a short distance with $\mathrm{CuA}$.

Nevertheless, in Enigmaptera, MA is distinctly separated from MP at wing base but still not fused with R, a very particular situation present in Eugeroptera, the Kukaloptera, the Argentinalidae, and the Geropteridae (Petrulevičius \& Gutiérrez 2016, Jacquelin et al. 2017), but not in the Neodonatoptera in which MA is appressed or fused to R, even in the most 'basal' clade Eomeganisoptera Rohdendorf 1962 (viz. Erasipteridae Carpenter 1939). Thus Enigmaptera corresponds to a completely new clade, sister group of the Neodonatoptera Enigmaptera is characterized by several autapomorphies: complete distal fusion of MP with R and MA, the strongly convex MA re-emerging from R in the arculus; very narrow wing, very narrow anal area, and very long RP1/2.

\section{Palaeoecological inferences}

The sub-petiolation of Enigmaptera is remarkable. Few Carboniferous petiolate wings of Odonatoptera are known, viz. the Protozygoptera Bechlyia Jarzembowski \& Nel 2002 (Farrington Formation, Upper Westphalian D, Kasimovian, UK) and Jacquesoudardia (Avion), the meganisopteran Bechalidae (Bechala Ilger \& Brauckmann 2012, Namurian, Germany) and the Meganeuridae Gallotupus ourdardi (which has a short petiole, also from Avion) (Jarzembowski \& Nel 2002, Nel et al. 2008, 2012; Prokop et al. 2014). Enigmaptera is a further convergent case of 'long' petioles (longer than the width) occurring in Odonatoptera. The others concern the Protozygoptera (Late Carboniferous to Early 
Cretaceous), the Triadophlebiomorpha (Triassic), Zygoptera (Mesozoic to recent), Stenophlebioptera (Mesozoic), and Epiophlebioptera (Cretaceous to recent). All these previously known cases concerned taxa belonging to the derived clade Discoidalia Bechly 1996 (characterized by the presence of a nodus and of a discoidal cell). Enigmaptera has no nodal structure, but a kind of 'basal complex' sensu Rajabi et al. (2016), viz. a structure composed by the shared point of fusion of MA, MP and R together with bases of RP and distal part of MA; plus the cell defined by $\mathrm{CuA}$, MP ending into R, and distal part of MA (Fig. 2). It is analogous, but not homologous, to the arculus plus discoidal cell of a Discoidalia and probably had the same function for deformations of the basal third of the wing.

Such small 'damselfly-like' Odonatoptera were probably living in close environments, hunting the small insects along the rivers or in forests, unlike the large to very large Meganisoptera, with wing span over $60 \mathrm{~cm}$ (Nel et al. 2009).

\section{Data access statement}

This study did not involve any underlying data. All specimens are available for re-study in the public institute indicated in the text.

\section{Acknowledgements}

We sincerely thanks Mr. Stéphane Carlier, Eiffage Route Nord Est, for their kind authorization to collect fossil insects in the terril of Avion.

\section{Disclosure statement}

No potential conflict of interest was reported by the authors. 


\section{Funding}

The work of JP was supported by the research project of the Grant Agency of the Czech Republic (No. 18-03118S).

\section{References}

Bechly, G., 1996. Morphologische Untersuchungen am Flügelgeäder der rezenten Libellen und deren Stammgruppenvertreter (Insecta; Pterygota; Odonata), unter besonderer Berücksichtigung der Phylogenetischen Systematik und des Grundplanes der *Odonata. Petalura Special Volume 2, 402 pp.

Engel, M.S., Davis, S.R. \& Prokop, J., 2013. Insect wings: the evolutionary development of Nature's first flyers. pp. 269-298. In: Minelli, A., G. Boxshall, \& G. Fusco (eds.). Arthropod biology and evolution: molecules, development, morphology. Springer Verlag, Berlin, Germany, ix +532 pp.

Fabricius, J.C., 1793. Entomologia Systematica Emendata et Aucta. Secundum Classes, Ordines, Genera, Species adiectis Synonymis, Locis, Observationibus, Descriptionibus, Volume 2. Impensis C.G. Proft fil. et soc., Hafniae (Copenhagen), viii +519 pp.

Jacquelin, L., Desutter-Grandcolas, L., Chintauan-Marquier, I., Boistel, R., Zheng, Daran, Prokop, J. \& Nel, A., 2018. New insights on basivenal sclerites using 3D tools and homology of wing veins in Odonatoptera (Insecta). Nature Scientific Reports 8 (238), 1-7.

Linnaeus, C., 1758. Systema Naturae per Regna Tria Naturae, secundum Classes, Ordines, Genera, Species, cum Characteribus, Differentiis, Synonymis, Locis. Tomus I. Laurentii Salvii, Holmiae (Stockholm), 823 pp.

Prokop, J., Roques, P. \& Nel, A., 2014. New non-holometabolous insects from Pennsylvanian of Avion locality in Pas-de-Calais, France (Insecta: 'Exopterygota'). Alcheringa 38, 155-169. 
Jarzembowski, E.A. \& Nel, A., 2002. The earliest damselfly-like insect and the origin of modern dragonflies (Insecta: Odonatoptera: Protozygoptera). Proceedings of the Geologist's Association 113, 165-169.

Martynov, A.V. 1923. [L'évolution de deux formes d'ailes différentes chez les insectes]. Revue Zoologique Russe 4, 155-185.

Martynov, A.V. 1932. New Permian Paleoptera with the discussion of some problems of their evolution. Trudy Paleozoologicheskogo Instituta Akademii nauk SSSR 1, 1-44. [in English, with summary in Russian.]

Nel, A., Fleck, G., Garrouste, R. Gand, G., Lapeyrie, J., Bybee, S.M. \& Prokop, J., 2009. Revision of Permo-Carboniferous griffenflies (Insecta: Odonatoptera: Meganisoptera) based upon new species and redescription of selected poorly known taxa from Eurasia. Palaeontographica (A) 289, 89-121.

Nel, A., Garrouste, R. \& Roques, P., 2008. A new griffenfly genus from the Late Carboniferous of northern France (Odonatoptera: Meganeuridae). Insect Systematics \& Evolution 39, 231-239.

Nel A., Ilger, J.-M., Brauckmann, C. \& Prokop, J., 2012. Revision of Bechala sommeri Ilger and Brauckmann, 2012 from the early Late Carboniferous of Germany (Insecta: Odonatoptera: Bechalidae). Insect Systematics \& Evolution 43, 161-169.

Nel, A., Martínez-Delclòs, X., Paicheler, J.-C. \& Henrotay, M., 1993. Les 'Anisozygoptera' fossiles. Phylogénie et classification (Odonata). Martinia Numéro Hors Série 3, 1-311.

Nel, A., Roques, P., Nel, P., Prokin, A.A., Bourgoin, T., Prokop, J., Szwedo, J., Azar, D., Desutter-Grandcolas, L., Wappler, T. Garrouste, R., Coty, D., Huang, Diying, Engel, M. \& Kirejtshuk, A.G., 2013. The earliest-known holometabolous insects. Nature 503, 257-261. Petrulevičius, J.F. \& Gutiérrez, P.R., 2016. New basal Odonatoptera (Insecta) from the Lower Carboniferous (Serpukhovian) of Argentina. Arquivos Entomolóxicos 16, 341-358. 
Prokop, J., Tippeltová, S., Roques, P. \& Nel, A., 2013. A new genus and species of Breyeriidae and wings of immature stages from the Upper Carboniferous, Nord-Pas-deCalais, France (Insecta: Palaeodictyoptera). Insect Systematics \& Evolution 44, 117-128.

Prokop, J., Roques, P. \& Nel, A., 2014. New non-holometabolous insects from Pennsylvanian of Avion locality in Pas-de-Calais, France (Insecta: 'Exopterygota'). Alcheringa 38, 155-169. Rajabi, H., Ghoroubi, N., Malaki, M., Darvizeh, A. \& Gorb, S.N., 2016. Basal complex and basal venation of Odonata wings: structural diversity and potential role in the wing deformation. PLoS ONE 11 (8) (e0160610), 1-17.

Riek, E.F. \& Kukalová-Peck, J., 1984. A new interpretation of dragonfly wing venation based upon Early Carboniferous fossils from Argentina (Insecta: Odonatoidea) and basic characters states in pterygote wings. Canadian Journal of Zoology 62, 1150-1166.

Fig. 1. Enigmaptera magnifica gen. nov, sp. nov., holotype Avion 35, wing photograph and reconstruction (scale bars $=2 \mathrm{~mm})$.

Fig. 2. Enigmaptera magnifica gen. nov, sp. nov., holotype Avion 35, wing base (scale bar 1 $\mathrm{mm})$. 

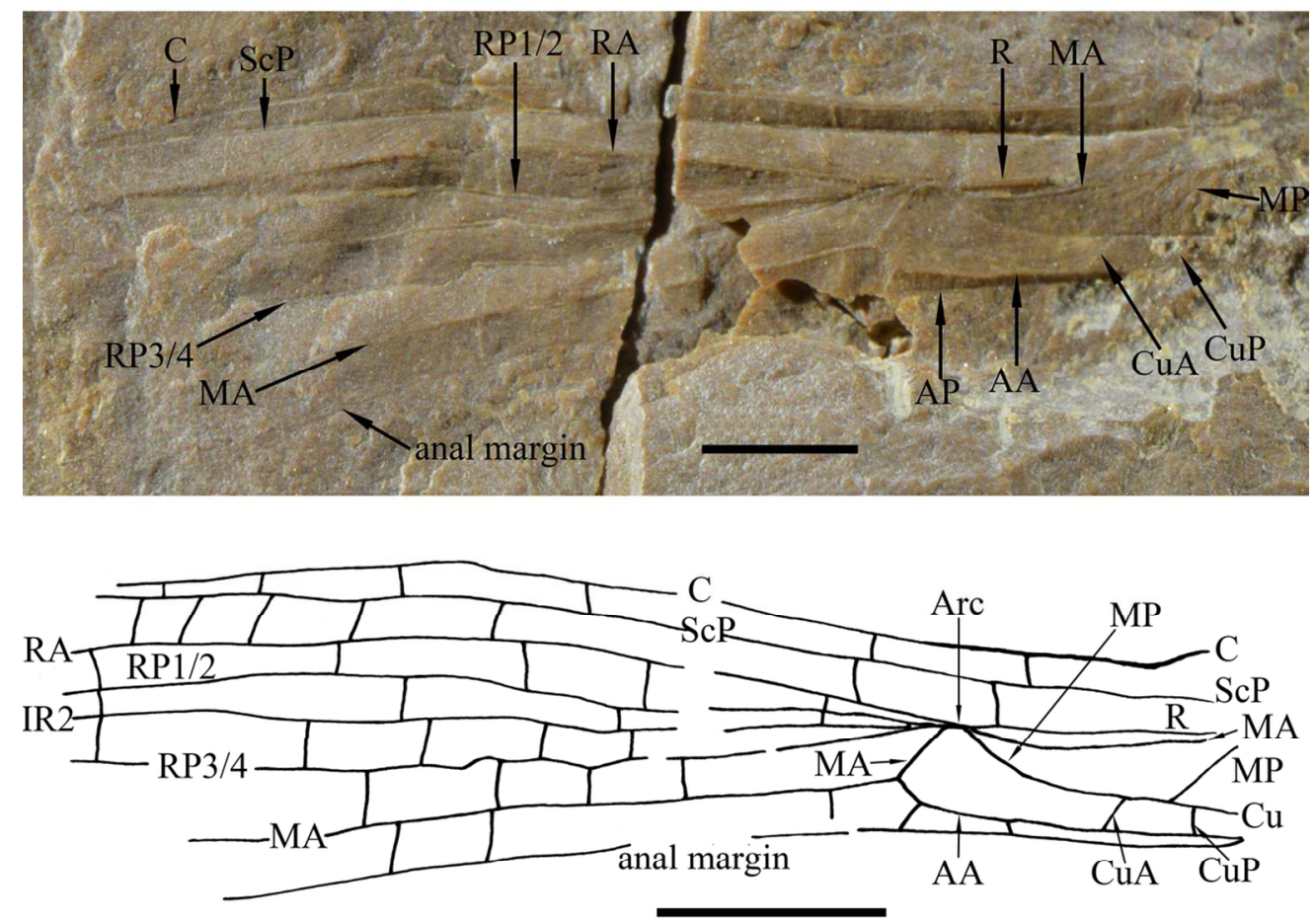

figure 1

$113 \times 86 \mathrm{~mm}(300 \times 300 \mathrm{DPI})$ 


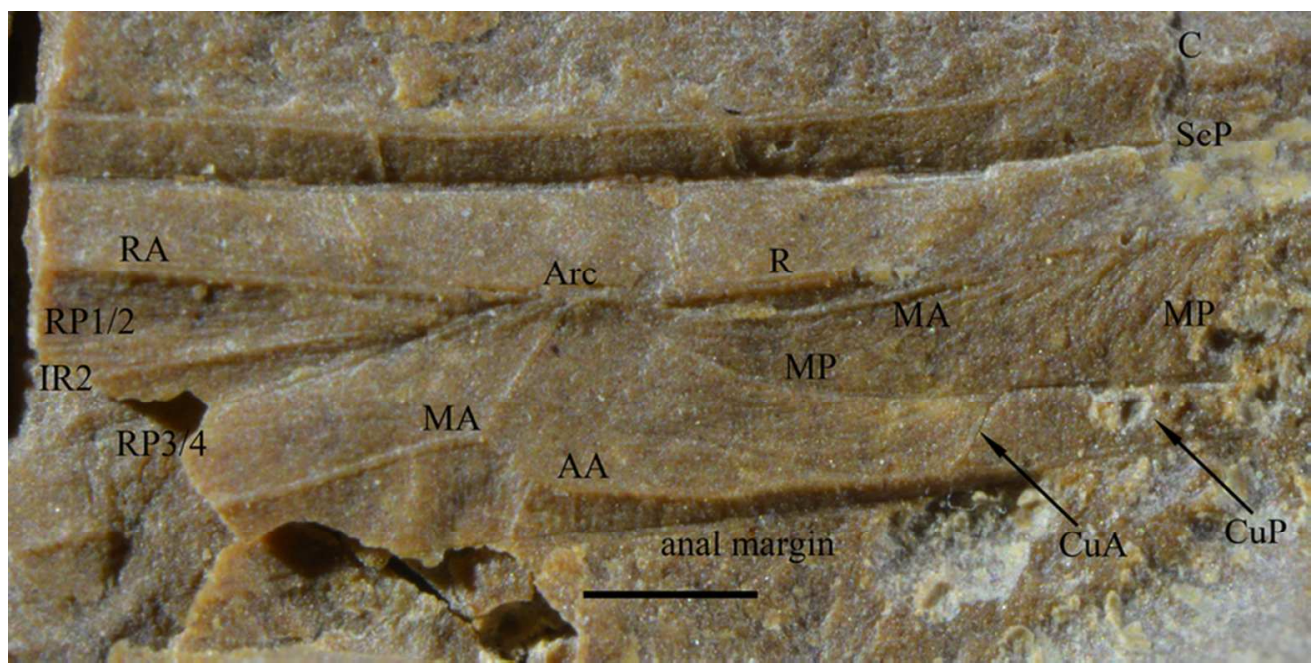

figure 2

$75 \times 37 \mathrm{~mm}(300 \times 300 \mathrm{DPI})$ 